\title{
Change in inflammation in out-patient COPD patients from stable phase to a subsequent exacerbation
}

\author{
Erik Bathoorn' \\ Jeroen JW Liesker' \\ Dirkje S Postma' \\ Gerard H Koëter' \\ Marco van der Toorn ${ }^{2}$ \\ Sicco van der $\mathrm{Heide}^{2}$ \\ $\mathrm{H}$ Alec Ross ${ }^{3}$ \\ Antoon JM van \\ Oosterhout ${ }^{2}$ \\ Huib AM Kerstjens' \\ 'Department of Pulmonology; \\ ${ }^{2}$ Laboratory of Allergology \\ and Pulmonary Diseases, Groningen \\ Research Institute for Asthma \\ and COPD (GRIAC), University \\ Medical Center Groningen, University \\ of Groningen, the Netherlands; \\ ${ }^{3}$ Department of Chemical \\ Endocrinology, Radboud University \\ Nijmegen Medical Centre, the \\ Netherlands
}

Background: Inflammation increases during exacerbations of COPD, but only a few studies systematically assessed these changes. Better identification of these changes will increase our knowledge and potentially guide therapy, for instance by helping with quicker distinction of bacterially induced exacerbations from other causes.

Aim: To identify which inflammatory parameters increase during COPD exacerbations compared to stable disease, and to compare bacterial and non-bacterial exacerbations.

Methods: In 45 COPD patients (37 male/8 female, 21 current smokers, mean age 65, FEV $52 \%$ predicted, pack years 38 ) sputum was collected during a stable phase and subsequently during an exacerbation.

Results: Sputum total cell counts $\left(9.0\right.$ versus $\left.7.9 \times 10^{6} / \mathrm{mL}\right)$, eosinophils $(0.3$ versus $\left.0.2 \times 10^{6} / \mathrm{mL}\right)$, neutrophils $\left(6.1\right.$ versus $\left.5.8 \times 10^{6} / \mathrm{mL}\right)$, and lymphocytes $(0.07$ versus $0.02 \times 10^{6} / \mathrm{mL}$ ) increased significantly during an exacerbation compared to stable disease. A bacterial infection was demonstrated by culture in 8 sputum samples obtained during an exacerbation. These exacerbations had significantly increased sputum total cell and neutrophil counts, leukotriene-B4, myeloperoxidase, interleukin-8 and interleukin-6, and tumor necrosis factor- $\alpha$ (TNF- $\alpha)$ levels, and were also associated with more systemic inflammation compared to exacerbations without a bacterial infection. Sputum TNF- $\alpha$ level during an exacerbation had the best test characteristics to predict a bacterial infection.

Conclusion: Sputum eosinophil, neutrophil, and lymphocyte counts increase during COPD exacerbations. The increase in systemic inflammation during exacerbations seems to be limited to exacerbations caused by bacterial infections of the lower airways. Sputum TNF- $\alpha$ is a candidate marker for predicting airway bacterial infection.

Keywords: chronic obstructive pulmonary disease, exacerbation, inflammation, sputum induction

\section{Introduction}

The frequent occurrence of exacerbations is an important feature of chronic obstructive pulmonary disease (COPD). The impact of exacerbations on a patient's health is large since they are remarkably closely linked to quality of life, accelerated lung function loss, and to mortality. ${ }^{1,2}$ There is also a huge impact on society since the direct costs to the health care system associated with the management of acute exacerbations of COPD are enormous. ${ }^{3}$ Notwithstanding this, there is still no universally accepted definition of a COPD exacerbation though several have been proposed. ${ }^{4-7}$ All definitions of exacerbation focus on symptoms, sometimes in combination with infectious etiology and/or airway obstruction, but remarkably, none of the definitions make any reference to changes or increases in inflammation. This is especially relevant since inflammation is part of the definition of COPD,${ }^{6}$ and most clinicians hold the general perception that exacerbations are associated with changes in airway inflammation. 
There is limited understanding of the causes of exacerbations, and, linked to this of the optimal treatment in relation to the cause. This has resulted in large international differences in the prescription levels of most notably antibiotics, given the lack of sufficient guidance to prescribe antibiotics or none. This is partially due to the fact that results of sputum cultures have quite a delay before test results are known. Thus a quicker detection of bacterial infections during COPD exacerbations should also lead to improvements in clinical care by aiding in the decision whether to start antibiotics. A few markers have been proposed, such as $\mathrm{C}$-reactive protein (CRP), and procalcitonin, ${ }^{8,9}$ but none have good test characteristics or have gained wide acceptance so far.

The aim of the current study is to identify which inflammatory parameters are increased in induced sputum and in blood during COPD exacerbations compared to a stable phase of the disease, and specifically to assess which parameters change during a bacterial exacerbation. Some of the present results have been described in the form of an abstract. ${ }^{10}$

\section{Methods}

Patients with a diagnosis of COPD were included if age $>40$ years, post-bronchodilator forced expiratory flow in the first second $\left(\mathrm{FEV}_{1}\right)<85 \%$ predicted and $>0.7 \mathrm{~L}$, postbronchodilator $\mathrm{FEV}_{1}$ /slow inspiratory vital capacity (IVC) $<$ predicted normal $(<88 \%$ predicted in men and $<89 \%$ predicted in women), ${ }^{11}$ and were current or ex smokers. Patients were not allowed to use oral corticosteroids, long-acting anticholinergics, beta-blockers, or long term oxygen therapy, have a history of asthma, or a significant other disease that could interfere with results of the study. The local medical ethics committee approved the study. A written informed consent was obtained from all patients prior to the study.

\section{Study design}

In case inhaled corticosteroids (ICS) were being used at inclusion, they were discontinued. Thereafter subjects had to be stable for 2 months. At the second visit, 2 months later, spirometry was performed followed by sputum induction; these measures were used as baseline, stable phase values in the study. From the second visit until the end of the randomized treatment period, all long-acting beta2-sympaticomimetics were also withdrawn. Patients were asked to contact the research doctor, who was available around the clock, to report any deterioration in symptoms for which they would normally contact their primary care physician or pulmonologist. An exacerbation was defined as a history of increased breathlessness and at least two of the following symptoms for 24 hours or more: increased cough frequency or severity, sputum volume or purulence, and wheeze. When presenting with an exacerbation, patients were randomized provided postbronchodilator $\mathrm{FEV}_{1}$ was $<70 \%$ of predicted and $\mathrm{PaO}_{2}>8.0 \mathrm{kPa}$. After this, a randomized controlled trial followed (data not shown).

\section{Measurements}

At each visit, sputum induction, blood sampling, and lung function measurements were performed. $\mathrm{FEV}_{1}$ and IVC were measured according to the guidelines of the European Respiratory Society. ${ }^{12}$

Health status was measured by the Clinical COPD Questionnaire. $^{13}$

\section{Sputum induction and processing}

Sputum was induced by standard methods with modifications according to Pizzichini. ${ }^{14}$ Whole sputum samples were processed within 120 minutes as described previously. ${ }^{15}$ Cytospins were prepared and cell-free supernatant was collected and stored in aliquots at $-80^{\circ} \mathrm{C}$ pending analyses of soluble mediators.

Differential cell counts were counted on May Grünwald Giemsa stained cytospins in a blinded fashion. ${ }^{16}$ Cell counts were expressed as percentage of non-squamous cells. A sputum sample was considered inadequate when the percentage squamous cells was $>80 \%$.

The following soluble mediators were measured in sputum supernatant by ELISA: leukotriene-B4 (LTB4, Amersham Biosciences, UK), eosinophilic cationic protein (ECP, Pharmacia, Uppsala, Sweden), myeloperoxidase (MPO, homemade ${ }^{17}$ ). Albumin in sputum and blood was measured by nephelometry (Dade Behring, Leusden, the Netherlands). Sputum interleukin-6 (IL-6), IL-8, tumor necrosis factor- $\alpha$ (TNF- $\alpha$ ), monocyte chemoattractant protein-1 (MCP-1), and both serum IL-6 and TNF- $\alpha$ were measured by xMAP technology (Luminex B.V., Oosterhout, the Netherlands), using multiplex immunoassay kits obtained from Linco, St Charles, USA.

\section{Bacterial culturing}

Spontaneous sputum samples were cultured. A bacterial cause of exacerbation was defined by the following features: the cultured micro-organisms are potentially pathogenic, the growth density in the culture is high (semi quantitative), the number of squameous epithelial cells is $<25$, and the number of the leukocytes in the Gram-stained preparation of the sputum sample is $>15$ per high power field $(100 \times 10)$, which corresponds with Geckler group 4-6). ${ }^{18}$ 


\section{Sputum cytokine mRNA expression}

Messenger ribonucleic acid (mRNA) was harvested from 1 million viable non-squamous sputum cells. RNA was isolated using a Qiagen RNeasy mini kit (Venlo, The Netherlands) and cDNA was synthesized as described..$^{19}$ Expression of cytokine mRNA was analyzed by quantitative real-time PCR, using the ABI 7900 HT system (Applied Biosystems, Nieuwekerk a/d IJssel, The Netherlands). The gene expression assays for hem-oxygenase-1 (HO-1), TNF- $\alpha$, chemotactic cytokine ligand5 (CCL5), IL-5, IL-10, IL-12, IL-13, transforming growth factor- $\beta$ (TGF- $\beta$ ), interferon- $\gamma$ (IFN- $\gamma$ ), and $\beta$-2-microglobulin, were obtained from Applied Biosystems (Nieuwekerk a/d IJssel, Netherlands). Cytokine gene expression was normalized to the expression of $\beta$-2-microglobulin. The mRNA quantification is expressed in threshold cycle values (Ct-values), which is the number of amplification cycles to reach a detectable mRNA amount. Thus lower Ct-values correspond with higher mRNA expression.

\section{Blood analyses}

Blood differential counts were analyzed by flow cytometry (Coulter-STKS, Beckman Coulter, Miami, USA). Serum C-Reactive Protein (CRP) and albumin were measured by nephelometry (Dade Behring, Leusden, the Netherlands).

\section{Statistical analysis}

Data are expressed as medians and inter quartile ranges (IQR). Non-normally distributed parameters were normalized by $\log _{10}$ transformation. Stable phase levels of inflammatory parameters were compared to exacerbation levels using paired sample t-tests, or Wilcoxon log rank tests. Exacerbations with and without a bacterial infection were compared with respect to both the cross-sectional values at exacerbation and the differences in the percentage change of biomarkers from baseline to exacerbation ( $t$-tests or Mann-Witney U-test). Using Receiver Operating Curves, cut-off points for the biomarkers were adjusted until the highest area under the curve was reached. Data were analyzed using SPSS version 12.0.2.

\section{Results}

We included 114 patients in this study. Some patients did not sustain corticosteroid withdrawal, or did not remain stable in the run in period $(n=9)$, other patients did not report an exacerbation $(n=26)$, or were excluded due to an adverse event $(n=4)$, or due to various other reasons $(n=30)$. The remaining 45 patients reporting an exacerbation within the study period were analyzed. The baseline characteristics of these patients are presented in Table 1. During the exacerbation, patients had a significantly and clinically relevant poorer health status as measured by higher CCQ scores compared to the stable phase (median value 2.5 versus 1.7 respectively, $p<0.01)$. The minimal clinically important difference of the CCQ is $0.4{ }^{20}$

\section{Inflammatory indices}

Sputum samples were adequate in both the stable phase, after ICS withdrawal, and during exacerbation in 41 out of 45 patients. The cellular differences between the stable phase ( 2 months after ICS withdrawal) and during the exacerbation are presented in Table 2. Sputum total cell, eosinophil, neutrophil, and lymphocyte counts were significantly increased at exacerbation versus stable disease.

Analyses of mRNA levels in sputum showed a lower IL-12a expression at exacerbation compared to stable state values (median ct-values 41.5 versus 37.7 respectively; $\mathrm{p}=0.051$ ). No differences were found in sputum mRNA

Table I Patient characteristics of the patients who had an exacerbation during the trial $(n=45)$, and of the total study population $(n=1$ I4)

\begin{tabular}{|c|c|c|}
\hline & Patients with exacerbation & Total study population \\
\hline Male/female & $37 / 8$ & $93 / 21$ \\
\hline Age, years ${ }^{\mathrm{a}}$ & $65(58-7 I)$ & 64 (59-7I) \\
\hline Smoked, pack-years ${ }^{\mathrm{a}}$ & $38(26-49)$ & $40(27-5 I)$ \\
\hline Smoking status, current/ex & $21 / 24$ & $47 / 67$ \\
\hline Body mass index, $\mathrm{kg} / \mathrm{m}^{2 a}$ & $25(24-28)$ & $26(24-28)$ \\
\hline $\mathrm{FEV}_{1}, \%$ pred $^{\mathrm{a}}$ & 61 (48-73) & $63(52-73)$ \\
\hline $\mathrm{FEV}_{\mathrm{I}} / \mathrm{IVC}, \%$ & $44(38-53)$ & $63(51.7-72.7)$ \\
\hline Reversibility, \% of pred ${ }^{a}$ & $8.9(5.3-11.0)$ & $8.9(5.5-11.8)$ \\
\hline CCQ-score ${ }^{a}$ & $1.7(1.3-2.1)$ & $1.7(1.3-2.6)$ \\
\hline
\end{tabular}

a Median (interquartile range).

Abbreviations: n, number; pred, predicted; CCQ, Clinical COPD Questionnaire. 
Table 2 Cellular inflammatory parameters

\begin{tabular}{|c|c|c|}
\hline & Stable & Exacerbation \\
\hline \multicolumn{3}{|l|}{ Sputum } \\
\hline Total cells $\times 10^{6} / \mathrm{mL}$ & $7.9(2.1-19.2)$ & $9.0(4.0-29.8)^{*}$ \\
\hline Eosinophil, \% & $2.7(0.8-5.8)$ & $2.8(0.8-4.8)$ \\
\hline Eosinophil $\times 10^{6} / \mathrm{mL}$ & $0.2(0.1-0.4)$ & $0.3(0.1-0.7)^{*}$ \\
\hline Neutrophils, \% & $71.7(65.3-80.0)$ & $72.0(62.1-86.1)$ \\
\hline Neutrophils $\times 10^{6} / \mathrm{mL}$ & $5.8(1.5-13.4)$ & $6.1(2 . I-24 . I)^{*}$ \\
\hline Macrophages, \% & $20.7(14.5-26.8)$ & $17.7(10.1-24.9)$ \\
\hline Macrophages $\times 10^{6} / \mathrm{mL}$ & $1.4(0.5-3.7)$ & $2.1(0.6-4.1)$ \\
\hline Lymphocytes, \% & $0.3(0.0-1.3)$ & $0.8(0.3-1.3)^{*}$ \\
\hline Lymphocytes $\times 10^{6} / \mathrm{mL}$ & $0.02(0.00-0.10)$ & $0.07(0.03-0.20)^{*}$ \\
\hline \multicolumn{3}{|l|}{ Blood } \\
\hline Leukocytes $\times 10^{9} / \mathrm{mL}$ & $6.6(6.0-8.2)$ & $7.5(5.9-9.1)^{*}$ \\
\hline Eosinophil, \% & $3.2(2.2-5.8)$ & $2.9(1.9-5.8)$ \\
\hline Eosinophil, $\times 10^{9} / \mathrm{mL}$ & $0.2(0.2-0.3)$ & $0.2(0.1-0.4)$ \\
\hline Neutrophils, \% & $61.0(55.4-65.9)$ & $63.0(57.2-68.2)$ \\
\hline Neutrophils, $\times 10^{9} / \mathrm{mL}$ & $4.2(3.5-4.9)$ & $4.6(3.4-6.1)^{*}$ \\
\hline Monocytes, \% & I0.I (8.3-II.0) & $8.8(7.9-10.8)$ \\
\hline Monocytes, $\times 10^{9} / \mathrm{mL}$ & $0.6(0.5-0.8)$ & $0.7(0.6-0.8)$ \\
\hline Lymphocytes, \% & $24.4(20.2-28.8)$ & $22.9(20.4-27.1)$ \\
\hline Lymphocytes, $\times 10^{9} / \mathrm{mL}$ & $1.6(1.4-2.0)$ & $1.7(1.4-2.0)$ \\
\hline
\end{tabular}

Note: $4 \mathrm{I}$ of 45 patients had an adequate sample for sputum cell differential analysis at both stable phase and exacerbation.

Median (interquartile range). *significant difference $(p<0.05)$.

levels of HO-1, TNF- $\alpha$, IL-5, CCL5, IL-10, IL-12b, IL-13, TGF- $\beta$, and INF- $\gamma$ (data not shown). The sputum protein levels of ECP, MCP-1, and LTB-4, were significantly increased at exacerbation compared to stable state and levels of MPO and IL-8 tended to be increased (Table 3).

Systemic inflammation during COPD exacerbations was increased compared to the stable phase, ie, blood leukocyte and neutrophil counts were significantly increased (Table 2), as were serum protein levels of IL-6 (Table 3 ). There was a trend towards an increase in CRP $(\mathrm{p}=0.07)$.

\section{Bacterial cultures}

Eight sputum samples for bacterial culture during exacerbation of COPD were missing: 5 patients produced too small a volume of spontaneous sputum, and 3 samples were missing due to logistical problems. Eight of the remaining 37 sputum samples were indicative of a bacterial infection: 5 with Haemophilus influenzae, 2 with Moraxella catarrhalis, and 1 with Streptococcus pneumoniae. These patients had a negative culture in stable phase. In stable phase, 10 patients produced too small a volume of spontaneous sputum and 1 was missing due to logistical problems.
Two of the remaining 34 samples were indicative of a bacterial infection ( $H$. influenzae and combination of $H$. influenzae and $M$. catarrhalis). These 2 patients had a negative culture during exacerbation.

\section{Differences between bacterial}

\section{and non-bacterial exacerbations}

Table 4 shows the differences between bacterial and nonbacterial exacerbations both cross-sectionally at the exacerbation visit, and as a change from baseline with stable disease to the exacerbation in order to correct for stable phase values.

Bacterial exacerbations were accompanied by higher values for sputum total cell and neutrophil counts, LTB4, MPO, IL-8, and TNF- $\alpha$ level than non bacterial exacerbations. In serum, bacterial exacerbations were associated with higher total leukocytes and neutrophil counts. Additionally, when analyzed as the percentage change from baseline to exacerbation, serum CRP and IL-6 levels showed a significantly larger increase when a bacterial exacerbation occurred compared to exacerbations without a bacterial infection.

The predictive values of the level of blood CRP, sputum TNF- $\alpha$ and sputum MPO for a bacterial cause of the exacerbation are presented in Receiver Operating Curves (Figure 1). Sputum TNF- $\alpha$ had the best test characteristics.

\section{Discussion}

The present study assessed the change in inflammation from a stable phase of COPD to an out-patient COPD exacerbation. Eight patients had a sputum sample indicative of a bacterial infection. None of these patients had a positive culture in stable phase. Sputum neutrophil, lymphocyte, and eosinophil numbers increased during an exacerbation. Furthermore, systemic inflammation increased during exacerbations as assessed by blood total leukocyte and neutrophil counts, and serum CRP and IL-6. These biomarkers were particularly increased in case of bacterial exacerbations. The level of sputum TNF- $\alpha$ during an exacerbation was the best predictor of a bacterial airway infection.

Airway inflammation during COPD exacerbations has been the focus of a few studies but their results have been inconsistent. ${ }^{21-26}$ This inconsistency can be explained by several factors. Firstly, it is difficult to gain information regarding airway inflammation during COPD exacerbations. Sputum induction by inhaled saline can cause additional bronchoconstriction and analysis of spontaneously produced sputum samples yields less cell viability, ${ }^{27}$ whereas more invasive techniques such as bronchoscopy are even more difficult to 
Table 3 Inflammatory biomarkers

\begin{tabular}{|c|c|c|c|}
\hline & Stable & Exacerbation & p-value \\
\hline \multicolumn{4}{|l|}{ Sputum } \\
\hline LTB-4 ng/mL & $0.4(0.2-0.7)$ & $0.5(0.3-1.1)$ & 0.03 \\
\hline TNF- $\alpha$ pg/mL & $1.6(1.6-8.7)$ & $4.6(1.6-31.5)$ & 0.37 \\
\hline IL-6 pg/mL & $287(183-637)$ & $361(164-783)$ & 0.24 \\
\hline $\mathrm{IL}-8 \mu g / \mathrm{mL}$ & $1.5(0.9-4.4)$ & $2.0(1.2-6.3)$ & 0.07 \\
\hline MCP-I pg/mL & $119(63-560)$ & $210(137-385)$ & 0.01 \\
\hline $\mathrm{MPO} \mu \mathrm{g} / \mathrm{mL}$ & $9.2(5.3-3 \mid .0)$ & I5.I (8.4-56.0) & 0.08 \\
\hline $\mathrm{ECP} \mu g / \mathrm{mL}$ & $85.4(49.6-319.5)$ & | $87.0(8 \mid .3-295.0)$ & 0.03 \\
\hline \multicolumn{4}{|l|}{ Serum } \\
\hline IL-6 pg/mL & $0.4(0.1-4.0)$ & $0.6(0.1-9.9)$ & 0.03 \\
\hline TNF- $\alpha$ pg/mL & $4.9(3.3-6.8)$ & $4.5(2.6-6.9)$ & 0.90 \\
\hline sICAM ng/mL & $109(91-129)$ & 118 (105-132) & 0.13 \\
\hline CRP mg/L & $3.4(1.8-8.2)$ & $3.6(1.5-17.1)$ & 0.07 \\
\hline \multicolumn{4}{|l|}{ Sputum/serum } \\
\hline Albumin ratio & $1.7(0.9-3.5)$ & $2.0(1.1-3.3)$ & 0.03 \\
\hline
\end{tabular}

Median (interquartile range). Analyzed for differences with paired t-tests.

Abbreviations: LTB4, leukotriene-B4;TNF- $\alpha$, tumor necrosis factor- $\alpha$; IL-6, interleukin-6; IL-8, interleukin-8; MCP-I, monocyte chemoattractant protein-I; MPO, myeloperoxidase; $\mathrm{ECP}$, eosinophilic cationic protein; sICAM, soluble intercellular adhesion molecule; CRP, C-reactive protein.

perform during exacerbations. Secondly, the causes of COPD exacerbations are heterogeneous. It is possible that well known inducing factors such as viruses, bacteria, and air pollution lead to different inflammatory patterns. ${ }^{6}$ Additionally, the specific focus of a study may well bias the selection of patients, for instance in the case of studies assessing the efficacy of antibiotics. Thirdly, the use of medication by patients with COPD can influence the inflammatory pattern, as is known with inhaled corticosteroids. ${ }^{28}$

This study was part of a randomized controlled trial studying the anti-inflammatory treatment effects of budesonide/formoterol therapy versus prednisolone during COPD exacerbations. ${ }^{29}$ To study these effects without biasing effects of maintenance therapy, inhaled corticosteroids were withdrawn if used. This study design also allowed us to study the change in inflammation from stable disease prospectively, non-modulated by inhaled corticosteroid therapy. The results should therefore be extrapolated only to similar patients, ie, not on steroids. Whether the same findings hold true for patients on inhaled corticosteroids remains to be established.

As expected, there was an increase in sputum neutrophils during COPD exacerbations. ${ }^{23,26,30}$ The increase in sputum neutrophil numbers was accompanied by an increase in sputum levels of LTB4 and IL-8, both attractants of neutrophils, and the neutrophil degranulation product MPO. These changes confirm an earlier study of Gompertz et $\mathrm{al}^{31}$ reporting a decrease in airway inflammation from the start of a COPD exacerbation to its resolution. These authors also reported a change in microvascular leakage as determined by the sputum/serum albumin ratio, which we confirm in our prospective study.

Furthermore, we found an increase of sputum lymphocytes during exacerbations. Lymphocytes play an important role in the pathogenesis of COPD. They are related to its development and progression. Lams et al found that smokers who develop COPD have increased CD8+ T-cells in large airways compared to asymptomatic smokers. ${ }^{32}$ Furthermore, there is an increase in $\mathrm{CD}^{+}$cells in patients with COPD, particularly as the disease progresses. ${ }^{33}$ This increase in lymphocytes has been suggested to be caused by chronic immune stimulation due to infectious pathogens. ${ }^{34}$ Not only T-cells, but also B-cells are increased in stable COPD. ${ }^{35-37}$ Although in this study we did not succeed in identifying viruses in induced sputum samples for an unknown but presumably technical reason, we still believe that viral airway infections may contribute in this respect. ${ }^{38,39}$ An autoimmune origin has also been suggested. ${ }^{35,40,41}$ Whether part of the increase in lymphocytes in our study is of B-cell origin was not evaluated.

This is at least the forth report documenting an increase in eosinophil counts during exacerbations. ${ }^{25,30,42}$ Next to the increase in eosinophils, we also found increased sputum ECP. ECP has been associated with tissue damage and tissue remodelling in in vitro studies. ${ }^{43}$ This might thus contribute 
Table 4a Differences between bacterial and non-bacterial exacerbations (sputum parameters)

\begin{tabular}{|c|c|c|c|c|}
\hline \multirow[t]{2}{*}{ Sputum } & \multicolumn{2}{|c|}{ Cross-sectional values at exacerbation } & \multicolumn{2}{|c|}{$\begin{array}{l}\text { Change from stable phase } \\
\text { to exacerbation (\%) }\end{array}$} \\
\hline & $\begin{array}{l}\text { Bacterial } \\
\text { exacerbation }\end{array}$ & $\begin{array}{l}\text { Non-bacterial } \\
\text { exacerbation }\end{array}$ & $\begin{array}{l}\text { Bacterial } \\
\text { exacerbation }\end{array}$ & $\begin{array}{l}\text { Non-bacterial } \\
\text { exacerbation }\end{array}$ \\
\hline total cell $\times 10^{6} / \mathrm{mL}^{\dagger \dagger}$ & $51.1(21.2-66.6)^{*}$ & $7.60(2.94-22.9)$ & $269(44-3183)^{\ddagger}$ & $-5(-36$ to -95$)$ \\
\hline eosinophil $\times 10^{6} / \mathrm{mL}^{\dagger \dagger}$ & $0.49(0.22-1.30)$ & $0.29(0.06-0.79)$ & $134(-22$ to -1460$)$ & $51(-34$ to -174$)$ \\
\hline neutrophil $\times 10^{6} / \mathrm{mL}^{\dagger \dagger}$ & $47.4(13.2-60.2)^{*}$ & $4.85(1.91-17.2)$ & $203(35-760)^{\ddagger}$ & $4(-39$ to -87$)$ \\
\hline lymphocyte $\times 10^{6} / \mathrm{mL}^{\text {抿 }}$ & $0.22(0.05-0.56)$ & $0.07(0.03-0.2 I)$ & $949(33-3815)$ & II $4(-3 \mid$ to -482$)$ \\
\hline $\mathrm{ECP} \mu \mathrm{g} / \mathrm{mL}^{\dagger \dagger}$ & $247(139-100 \mid)$ & $187(96.9-279)$ & $137(9-222)$ & $50(-20$ to -183$)$ \\
\hline 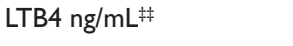 & $\mathrm{I} .43(0.7 \mathrm{I}-2.0 \mathrm{I})^{*}$ & $0.43(0.34-0.59)$ & $164(50-347)^{\ddagger}$ & $0(-26$ to -54$)$ \\
\hline $\mathrm{MPO} \mu \mathrm{g} / \mathrm{mL}^{\dagger \dagger}$ & $57.7(30.4-89.9)^{*}$ & $12.6(6.29-34.6)$ & $349(-2$ to -955$)$ & $7(-34-102)$ \\
\hline IL-6 pg/mL ${ }^{\dagger+}$ & $680(267-|25|)$ & $325(153-733)$ & $116(52-610)^{\ddagger}$ & $-16(-47$ to -77$)$ \\
\hline $\mathrm{IL}-8 \mu \mathrm{g} / \mathrm{mL}^{\dagger \dagger}$ & $7.78(3.52-9.90)^{*}$ & $1.74(0.92-4.47)$ & $149(0-444)$ & $6(-23$ to -72$)$ \\
\hline 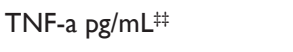 & $56.8(43.3-69.7)^{*}$ & $3.43(1.60-7.73)$ & $1580(9 \mid-583)^{\ddagger}$ & $0(-17$ to -110$)$ \\
\hline MCP-I pg/mL $\mathrm{m}^{\dagger \dagger}$ & 283 (I77-799) & $194(131-360)$ & $|4|(||-376)$ & $4 \mid(-32$ to $-|7|)$ \\
\hline Sputum/serum albumin & $3.06(2.44-3.65)$ & $1.99(1.14-3.11)$ & $51(15-85)$ & $35(-21$ to -100$)$ \\
\hline
\end{tabular}

Table 4b Differences between bacterial and non-bacterial exacerbations (blood parameters)

\begin{tabular}{|c|c|c|c|c|}
\hline & \multicolumn{2}{|c|}{ Cross-sectional values at exacerbation } & \multicolumn{2}{|c|}{$\begin{array}{l}\text { Change from stable phase } \\
\text { to exacerbation (\%) }\end{array}$} \\
\hline & $\begin{array}{l}\text { Bacterial } \\
\text { exacerbation }\end{array}$ & $\begin{array}{l}\text { Non-bacterial } \\
\text { exacerbation }\end{array}$ & $\begin{array}{l}\text { Bacterial } \\
\text { exacerbation }\end{array}$ & $\begin{array}{l}\text { Non-bacterial } \\
\text { exacerbation }\end{array}$ \\
\hline \multicolumn{5}{|l|}{ Blood/serum } \\
\hline leukocytes $\times 106 / \mathrm{mL}^{\dagger \dagger}$ & $8.95(7.95-10.3)^{*}$ & $6.60(5.70-8.15)$ & $24(I-53)^{\ddagger}$ & $2(-5$ to -18$)$ \\
\hline neutrophil $\times 106 / \mathrm{mL}^{\dagger \dagger}$ & $6.47(4.87-7.62)^{*}$ & $3.84(3.34-5.63)$ & $23(5-69)$ & $4(-14$ to -25$)$ \\
\hline $\mathrm{sICAM} \mu \mathrm{g} / \mathrm{mL}^{\dagger \neq}$ & $11.2(10.3-13.9)$ & $12.1(10.5-13.3)$ & II $(-5$ to -26$)$ & $4(-3$ to -13$)$ \\
\hline CRP mg/L” & $9.08(4.56-26.2)$ & $2.6(1.4-15.3)$ & $143(39-740)^{\ddagger}$ & I $(-42$ to -87$)$ \\
\hline 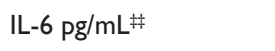 & $4.86(1.22-10.0)$ & $0.40(0.10-10.7)$ & $670(119 \text { to }-2225)^{\ddagger}$ & $0(-2$ to -126$)$ \\
\hline TNF-a $\mathrm{pg} / \mathrm{mL}^{\ddagger \dagger}$ & $4.50(2.33-7.36)$ & $4.60(2.61-7.00)$ & $-7(-23$ to -21$)$ & $-11(-21$ to -13$)$ \\
\hline
\end{tabular}

to the observed association between exacerbation frequency and excess decline in lung function. ${ }^{1}$ However, not all prior studies have found increases in eosinophils during COPD exacerbations. ${ }^{22}$ This difference between our and others' observation of an increase in eosinophils may be simply explained by a suppressive effect of the used steroids on sputum eosinophils in these studies. ${ }^{28}$

Neutrophil, and eosinophil sputum cell counts, were significantly increased, but not their percentages. This shows that absolute cell counts provide different information about inflammation than cell percentages. Absolute cell counts reflect the concentration of these cells and therefore the total load, whereas the percentage reflects an inflammatory pattern. Our data point out that there can be an increase in inflammation, without a significant change in the inflammatory pattern.

Next to increased sputum inflammation as proxy of airways inflammation, we also found increased systemic inflammation as demonstrated by increased number of blood total leukocytes, neutrophils, IL-6, and a trend in CRP during exacerbations. This confirms an earlier report of increased systemic inflammation (increased serum IL-6 and CRP) during COPD exacerbations. ${ }^{44,45}$ In $22 \%$ of our sputum samples the exacerbation was associated with a bacterial infection. These exacerbations showed a higher increase of total cell and neutrophil counts, IL-6, TNF- $\alpha$ levels in sputum, and leukocyte and neutrophil counts, CRP, and IL-6 levels in blood. This relationship of 
a)

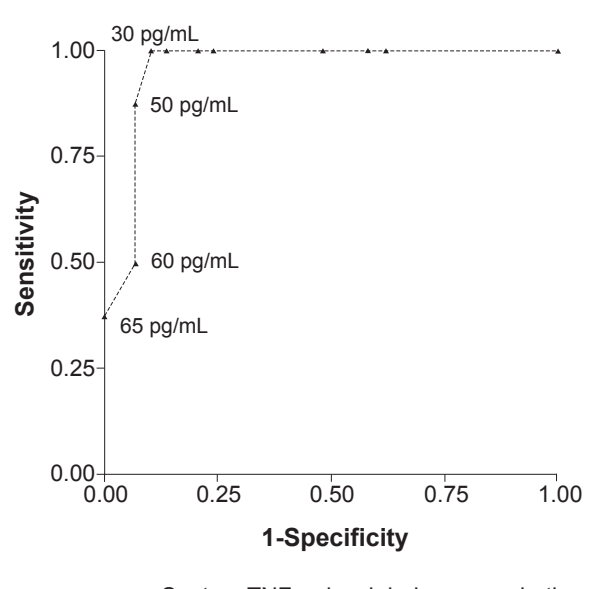

........ Sputum TNF - $\alpha$ level during exacerbation

b)

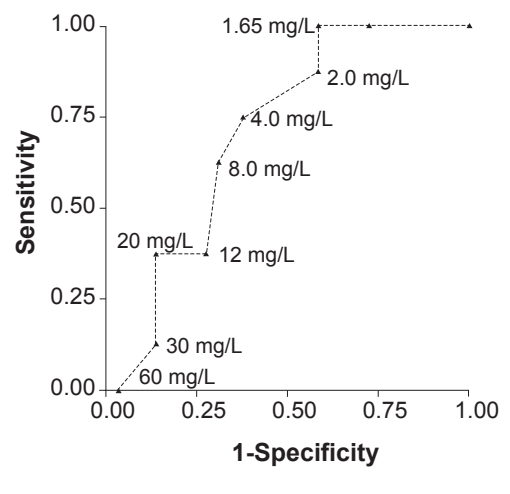

--Blood CRP level during exacerbation

c)

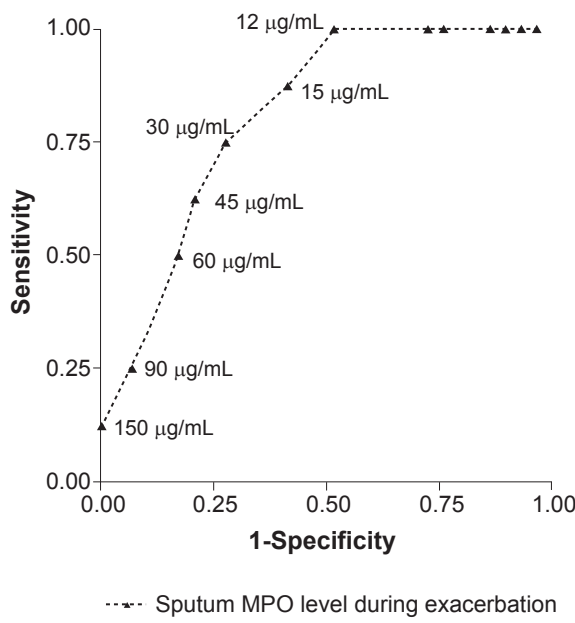

Figure I Receiver operating characteristic curves for distinguishing a bacterial cause of exacerbations with inflammatory markers. On the curve, several biomarker concentration levels are presented, which provides an indication for optimal cut-off points and their corresponding predictive values.

a) sputum tumor necrosis factor- $\alpha$ (TNF- $\alpha$ ), b) blood C-reactive protein (CRP) c) sputum myeloperoxidase (MPO). higher sputum and systemic inflammation in the presence of a bacterial pathogen in sputum has been reported in earlier studies, ${ }^{26,44}$ though not all studies have found this relationship. ${ }^{21}$ However, these studies did not investigate whether these high levels were already present in stable state, ${ }^{26,44}$ or, as we now show, indeed reflected an increase that occurs with a bacterial infection. Our data show that some of the biomarkers that are increased in an exacerbation actually only change if the specific exacerbation is induced by a bacterial infection.

Serum CRP has been investigated as a marker to identify exacerbations in one study. ${ }^{8}$ The predictive value of serum CRP alone was limited in that study, and use of the combination of the CRP level with a symptom of exacerbation was proposed to improve the predictive value of CRP. Our study shows that CRP is much more increased in bacterial exacerbations. We believe this underlines the limitations of CRP as a general biomarker of COPD exacerbations.

It would be of clinical use if clinicians would have biomarkers with cut-off points to differentiate which patient has a bacterial airway infection. If one would know from a rapidly available biomarker whether there is a high chance of a bacterial infection, this would improve the efficiency of use of antibiotic treatment. Our study population had mild to moderate COPD and is not large enough to provide firm data on such cut-off points, and we investigated exacerbations that did not require hospitalization. Nevertheless, we do present the receiver operating charateristic curves to offer reference and directions for future assessment of firm cut-off points. From our preliminary analyses, sputum TNF- $\alpha$ seems to be a good candidate biomarker in future studies. Sputum TNF- $\alpha$ levels were only increased in patients with a bacterial exacerbation, and not in patients with a non-bacterial exacerbation. Since the majority of patients did not have a bacterial exacerbation, the change in sputum TNF- $\alpha$ levels for the total group from stable to exacerbation was not significant (Table 3). This finding is supported by a study by Sethi et al which reports significantly increased sputum TNF- $\alpha$ levels in exacerbations with new bacterial strains. ${ }^{46}$ We do not have data on changes in strains: all patients with an bacterial exacerbation had negative cultures in stable phase.

In summary, this study showed an increase in neutrophilic, eosinophilic, and lymphocytic airway inflammation from a stable phase of disease to an exacerbation in outpatient COPD patients withdrawn from inhaled corticosteroids. In addition, systemic airway inflammation increased during exacerbations and of interest, this was limited to exacerbations with bacterial infections. Some of the biomarkers, specifically sputum LTB4, MPO, IL-6, TNF- $\alpha$, 
and serum CRP and IL-6, which are commonly associated with exacerbations, are increased during bacterial exacerbations, but little or not increased at all during non-bacterial exacerbations. Though our group of patients was too small to draw firm conclusions, the data lend support to further investigation of whether these inflammatory parameters, and specifically TNF- $\alpha$, provide a useful tool for identification of a bacterial infection in COPD.

\section{Abbreviations}

CCL-5, chemotactic cytokine ligand-5; CCQ, clinical COPD questionnaire; COPD, chronic obstructive pulmonary disease; CRP, C-reactive protein; $\mathrm{Ct}$, cycle threshold; ECP, eosinophilic cationic protein; $\mathrm{FEV}_{1}$, forced expiratory flow in one second; FVC, forced vital capacity, HO-1, heme oxygenase-1; IFN- $\gamma$, interferon- $\gamma$; IL, interleukin; IQR, interquartile range; LTB4, leukotriene-B4; MCP-1, monocyte chemoattractant protein-1; MPO, myeloperoxidase; mRNA, messenger ribonucleic acid; TGF- $\beta$, transforming growth factor- $\beta$; TNF- $\alpha$, tumor necrosis factor- $\alpha$; VC, slow inspiratory vital capacity.

\section{Acknowledgments}

The authors thank Ibolya Sloots, Brigitte Dijkhuizen, Koos van de Belt, and Janneke Heimweg for the sputum measurements, the lung function department for the many lung function measurements, and Dr N.E.L. Meessen for his help with the interpretation of sputum culture results.

\section{Disclosures}

This study was supported by a research grant from AstraZeneca, the Netherlands.

Erik Bathoorn's and Jeroen Liesker's salaries were paid by AstraZeneca.

Huib Kerstjens and Dirkje Postma receive funds for research from AstraZeneca and have competing arrangements with the competitors GlaxoSmithKline and Altana.

Gerard Koëter, Marco van der Toorn, Sicco van der Heide, and Antoon J.M. van Oosterhout have no conflicts of interests to declare.

\section{References}

1. Donaldson GC, Seemungal TA, Bhowmik A, Wedzicha JA. Relationship between exacerbation frequency and lung function decline in chronic obstructive pulmonary disease. Thorax. 2002;57(10):847-852.

2. Schmier JK, Halpern MT, Higashi MK, Bakst A. The quality of life impact of acute exacerbations of chronic bronchitis (AECB): a literature review. Qual Life Res. 2005;14(2):329-347.

3. McGuire A, Irwin DE, Fenn P et al. The excess cost of acute exacerbations of chronic bronchitis in patients aged 45 and older in England and Wales. Value Health. 2001;4(5):370-375.
4. Rodriguez-Roisin R. Toward a consensus definition for COPD exacerbations. Chest. 2000;117(5 Suppl 2):398S-401S.

5. Madison JM, Irwin RS. Chronic obstructive pulmonary disease. Lancet. 1998;352(9126):467-473.

6. Global Strategy for the Diagnosis, management and prevention of Chronic Obstructive Pulmonary Disease; updated 2006. available from http://www.goldcopd.com. 2006.

7. Anthonisen NR, Manfreda J, Warren CP, Hershfield ES, Harding GK, Nelson NA. Antibiotic therapy in exacerbations of chronic obstructive pulmonary disease. Ann Intern Med. 1987;106(2):196-204.

8. Hurst JR, Donaldson GC, Perea WR, et al. Utility of plasma biomarkers at exacerbation of chronic obstructive pulmonary disease. Am J Respir Crit Care Med. 2006;174(8):867-874.

9. Christ-Crain M, Jaccard-Stolz D, Bingisser R, et al. Effect of procalcitonin-guided treatment on antibiotic use and outcome in lower respiratory tract infections: cluster-randomised, single-blinded intervention trial. Lancet. 2004;363(9409):600-607.

10. Bathoorn D. Change in inflammation during COPD exacerbations. Eur Respir J. 2005;26 Suppl 49:15s.

11. Siafakas NM, Vermeire P, Pride NB, et al. Optimal assessment and management of chronic obstructive pulmonary disease (COPD). The European Respiratory Society Task Force. Eur Respir J. 1995;8(8):1398-1420.

12. Quanjer PH, Tammeling GJ, Cotes JE, Pedersen OF, Peslin R, Yernault JC. Lung volumes and forced ventilatory flows. Report Working Party Standardization of Lung Function Tests, European Community for Steel and Coal. Official Statement of the European Respiratory Society. Eur Respir J Suppl. 1993;16:5-40.

13. van der Molen T, Willemse BW, Schokker S, ten Hacken NH, Postma DS, Juniper EF. Development, validity and responsiveness of the Clinical COPD Questionnaire. Health Qual Life Outcomes. 2003;28;1(1):13.

14. Pizzichini MM, Pizzichini E, Clelland L, et al. Sputum in severe exacerbations of asthma: kinetics of inflammatory indices after prednisone treatment. Am J Respir Crit Care Med. 1997;155(5):1501-1508.

15. Rutgers SR, Timens W, Kaufmann HF, van der Mark TW, Koeter GH, Postma DS. Comparison of induced sputum with bronchial wash, bronchoalveolar lavage and bronchial biopsies in COPD. Eur Respir J. 2000;15(1):109-115.

16. Meijer RJ, Kerstjens HA, Arends LR, Kauffman HF, Koeter GH, Postma DS. Effects of inhaled fluticasone and oral prednisolone on clinical and inflammatory parameters in patients with asthma. Thorax. 1999;54(10):894-899.

17. Renkema TE, Postma DS, Noordhoek JA, Sluiter HJ, Kauffman HF. In vitro release of neutrophil elastase, myeloperoxidase and betaglucuronidase in patients with emphysema and healthy subjects. Eur Respir J. 1991;4(10):1237-1244.

18. Geckler RW, Gremillion DH, McAllister CK, Ellenbogen C. Microscopic and bacteriological comparison of paired sputa and transtracheal aspirates. J Clin Microbiol. 1977;6(4):396-399.

19. Borger P, Vellenga E, Gringhuis SI, et al. Prostaglandin E2 differentially modulates IL-5 gene expression in activated human T lymphocytes depending on the costimulatory signal. J Allergy Clin Immunol. 1998;101(2 Pt 1):231-240.

20. Kocks JW, Tuinenga MG, Uil SM, van den Berg JW, Stahl E, van der Molen T. Health status measurement in COPD: the minimal clinically important difference of the clinical COPD questionnaire. Respir Res. 2006;7:62.

21. Aaron SD, Angel JB, Lunau M, et al. Granulocyte inflammatory markers and airway infection during acute exacerbation of chronic obstructive pulmonary disease. Am J Respir Crit Care Med. 2001;163(2): 349-355.

22. Bhowmik A, Seemungal TA, Sapsford RJ, Wedzicha JA. Relation of sputum inflammatory markers to symptoms and lung function changes in COPD exacerbations. Thorax. 2000;55(2):114-120.

23. Fujimoto K, Yasuo M, Urushibata K, Hanaoka M, Koizumi T, Kubo K. Airway inflammation during stable and acutely exacerbated chronic obstructive pulmonary disease. Eur Respir J. 2005;25(4):640-646. 
24. Qiu Y, Zhu J, Bandi V, et al. Biopsy neutrophilia, neutrophil chemokine and receptor gene expression in severe exacerbations of chronic obstructive pulmonary disease. Am J Respir Crit Care Med. 2003;168(8):968-975.

25. Saetta M, Di Stefano A, Maestrelli P, et al. Airway eosinophilia in chronic bronchitis during exacerbations. Am J Respir Crit Care Med. 1994;150(6 Pt 1):1646-1652.

26. Papi A, Bellettato CM, Braccioni F, et al. Infections and airway inflammation in chronic obstructive pulmonary disease severe exacerbations. Am J Respir Crit Care Med. 2006;173(10):1114-1121.

27. Pizzichini MM, Popov TA, Efthimiadis A, et al. Spontaneous and induced sputum to measure indices of airway inflammation in asthma. Am J Respir Crit Care Med. 1996;154(4 Pt 1):866-869.

28. Barnes NC, Qiu YS, Pavord ID, et al. Antiinflammatory effects of salmeterol/fluticasone propionate in chronic obstructive lung disease. Am J Respir Crit Care Med. 2006;173(7):736-743.

29. Bathoorn E, Liesker JJ, Postma DS, et al. Anti-inflammatory effects of combined budesonide/formoterol in COPD exacerbations. COPD. 2008;5(5):282-290.

30. Mercer PF, Shute JK, Bhowmik A, Donaldson GC, Wedzicha JA, Warner JA. MMP-9, TIMP-1 and inflammatory cells in sputum from COPD patients during exacerbation. Respir Res. 2005;6:151.

31. Gompertz S, O’Brien C, Bayley DL, Hill SL, Stockley RA. Changes in bronchial inflammation during acute exacerbations of chronic bronchitis. Eur Respir J. 2001;17(6):1112-1119.

32. Roland M, Bhowmik A, Sapsford RJ, et al. Sputum and plasma endothelin-1 levels in exacerbations of chronic obstructive pulmonary disease. Thorax. 2001;56(1):30-35.

33. Majori M, Corradi M, Caminati A, Cacciani G, Bertacco S, Pesci A. Predominant TH1 cytokine pattern in peripheral blood from subjects with chronic obstructive pulmonary disease. J Allergy Clin Immunol. 1999;103(3 Pt 1):458-462.

34. Retamales I, Elliott WM, Meshi B, et al. Amplification of inflammation in emphysema and its association with latent adenoviral infection. Am J Respir Crit Care Med. 2001;164(3):469-473.

35. van der Strate BW, Postma DS, Brandsma CA, et al. Cigarette Smokeinduced Emphysema: A Role for the B Cell? Am J Respir Crit Care Med. 2006;173(7):751-758.
36. Gosman MM, Willemse BW, Jansen DF, et al. Increased number of B-cells in bronchial biopsies in COPD. Eur Respir J. 2006;27(1):60-64.

37. Hogg JC, Chu F, Utokaparch S, et al. The nature of small-airway obstruction in chronic obstructive pulmonary disease. $N$ Engl J Med. 2004;350(26):2645-2653.

38. Gerhard W, Mozdzanowska K, Furchner M, Washko G, Maiese K. Role of the B-cell response in recovery of mice from primary influenza virus infection. Immunol Rev. 1997;159:95-103.

39. Coro ES, Chang WL, Baumgarth N. Type I IFN receptor signals directly stimulate local B cells early following influenza virus infection. J Immunol. 2006;176(7):4343-4351.

40. Majo J, Ghezzo H, Cosio MG. Lymphocyte population and apoptosis in the lungs of smokers and their relation to emphysema. Eur Respir J. 2001;17(5):946-953.

41. Agusti A, MacNee W, Donaldson K, Cosio M. Hypothesis: does COPD have an autoimmune component? Thorax. 2003;58(10):832-834.

42. Fujimoto K, Yasuo M, Urushibata K, Hanaoka M, Koizumi T, Kubo K. Airway inflammation during stable and acutely exacerbated chronic obstructive pulmonary disease. Eur Respir J. 2005;25(4):640-646.

43. Zagai U, Skold CM, Trulson A, Venge P, Lundahl J. The effect of eosinophils on collagen gel contraction and implications for tissue remodelling. Clin Exp Immunol. 2004;135(3):427-433.

44. Hurst JR, Perera WR, Wilkinson TM, Donaldson GC, Wedzicha JA. Systemic and upper and lower airway inflammation at exacerbation of chronic obstructive pulmonary disease. Am J Respir Crit Care Med. 2006;173(1):716-718.

45. Seemungal T, Harper-Owen R, Bhowmik A, et al. Respiratory viruses, symptoms, and inflammatory markers in acute exacerbations and stable chronic obstructive pulmonary disease. Am J Respir Crit Care Med. 2001;164(9):1618-1623.

46. Sethi S, Wrona C, Eschberger K, Lobbins P, Cai X, Murphy TF. Inflammatory profile of new bacterial strain exacerbations of chronic obstructive pulmonary disease. Am J Respir Crit Care Med. 2008;177(5):491-497. 
